\title{
Can the Patient Survive the Cure? Irish Labour Law in the Austerity Era
}

\section{THIS IS AN EARLIER DRAFT OF AN ARTICLE NOW PUBISHED:}

\section{'CAN THE PATIENT SURVIVE THE CURE? IRISH LABOUR LAW IN THE AUSTERITY ERA' (2014) 5(1) EUROPEAN LABOUR LAW JOURNAL 82}

Michael Doherty*

\section{Abstract}

This article analyses the effects of the current socio-economic crisis on, and recent measures in the field of, labour law in Ireland. As one of the 'programme' countries, which has sought and recieved financial support from the Troika of the International Monetary Fund, European Central Bank and European Commission, Ireland has been required to follow a wide-ranging programme of measures designed to restore the economic health of the country. This article looks at specific measures taken in the sphere of labour law and policy, in the private and public sectors, placing these in the context of the wider EU picture.

\section{Keywords}

Crisis, Ireland, Troika, collective bargaining, public sector reform

\footnotetext{
- Professor of Law, Department of Law, National University of Ireland Maynooth, Maynooth, Co. Kildare, Ireland. Email: michael.b.doherty@nuim.ie .
} 


\section{Introduction}

'This is a significant day, that many thought, and some feared, would never be reached. The effort of the Irish people in working towards this goal has been unprecedented. Having been frozen out of the financial markets three years ago, we have now successfully laid the foundations for exiting the EU/IMF programme on December 15 of this year and for making a full return to the markets. Over 260 actions have been completed under the programme. Stability has been restored to the public finances, the economy is growing, and most importantly, over 3,000 jobs are being created each month. Over the course of the programme, a wide range of structural reforms have been introduced across the public service, the economy and the financial system'.

The words of the Minister for Finance, Michael Noonan, on 7 November 2013, as Ireland 'successfully concluded the $12^{\text {th }}$ and final review mission of the Programme with the EU Commission, the ECB (European Central Bank) and the IMF (International Monetary Fund)'. ${ }^{1}$ The Minister's words, and the majority of the more than 260 'actions' referred to, concentrate on economic and financial reforms (in particular, relating to the banking and finance sector). This article focuses primarily, though, on the 'structural reforms', as they relate to labour law and policy in Ireland. The article concentrates on two areas in particular; reform of sectoral wage-setting mechanisms and reform of public sector labour relations. The article proceeds as follows. In the next section, the 'Irish model' of industrial relations and labour law is outlined. The article then goes on to examine some of the specifics of the Irish crisis (although briefly, as they are, by now, relatively well-known and understood), and the

\footnotetext{
${ }^{1}$ http://www.merrionstreet.ie/index.php/2013/11/successful-completion-of-12th-and-final-reviewmission-of-the-eu-imf-programme/ (accessed 20 November 2013).
} 
role and demands of the Troika of the International Monetary Fund, European Central Bank and European Commission will be outlined. The next sections examine the impacts of the Troika-demanded reforms on wage-setting mechanisms in Ireland and on employment conditions and standard-setting in the public sector. The article concludes by reflecting on the likely legacy of these reforms for Ireland, in the context of the wider EU picture.

\section{The Irish Model (or the 'Model Irish'...?)}

The Irish system of employment relations has traditionally been classified as 'voluntarist', where the role of the State is primarily to provide a supportive framework for collective bargaining (rather than to regulate the labour market by way of legislation). ${ }^{2}$ Whilst, in the last two decades or so, a number of developments, notably the decline in trade union density and workplace presence since the 1980s and the obligations of EU membership, has resulted in a large volume of labour legislation being passed, the vast majority of legislative measures provides for rights in respect of individual workers. ${ }^{3}$ In terms of collective labour law, voluntarism, in the Irish context, means that there is no obligation on employers to recognise a trade union for collective bargaining purposes and collective agreements are generally not legally binding. ${ }^{4}$ Agreements are enforced through industrial relations (IR) negotiations and, if necessary through displays of IR 'muscle' (strikes or lock-outs, for example). Collective bargaining in Ireland, thus, is seen as normative; collective agreements are usually not legally enforceable, as they do not generally intend to

\footnotetext{
${ }^{2}$ Hyman, R., 'Industrial Relations in Europe: Theory and Practice' European Journal of Industrial Relations (1995), 1(1), p. 17.

3 Doherty, M. 'Developments in Legal Scholarship: Labour Law', in Mohr, T and Schweppe, J. (eds) 30 Years of Legal Scholarship (Dublin, Thomson Round Hall, 2011), p. 281.

${ }^{4}$ Kerr, A. and Whyte, G. Irish Trade Union Law (Dublin, Professional Books Limited, 1985), chapter 1.
} 
create legal relations. ${ }^{5}$ As a general rule, only the parties to an agreement are bound by its terms; concluded collective agreements do not produce erga omnes effects.

However, some important qualifications to this position must be noted. Collective agreements can be given legal effect if such agreements are registered with the Labour Court (known as Registered Employment Agreements; REAs). ${ }^{6}$ Although these can be individual agreements between a particular employer and its workers, in practice, REAs at the sectoral level, made between the main employer body representing employers in the sector and the trade unions representing workers in the industry, have traditionally been the most significant (particularly in the construction sector). Registered Employment Agreements apply to all employers and employees working in a particular sector or industry irrespective of whether such employers or employees were, in fact, parties to the agreement or wished to be subject to its terms. In addition, Joint Labour Committees (JLCs) provide for the fixing of minimum rates of pay and the regulation of employment in certain sectors where there is little or no collective bargaining and where significant numbers of vulnerable workers are employed (e.g. retail, catering and hotels). ${ }^{7} \mathrm{JLCs}$, which comprise of an independent chairperson, appointed by the Minister, and representative members of workers and employers, propose Employment Regulation

\footnotetext{
${ }^{5}$ Goulding Chemicals Ltd. v Bolger [1977] IR 211. See Holland v Athlone IT [2011] IEHC 414, where the High Court held that the Public Service Agreement 2010-2014 (the 'Croke Park Agreement'), made between public sector unions and management, could not be taken to have created enforceable legal rights which are justiciable in law at the hands of an individual public sector employee. Hogan $\mathrm{J}$ held that the language used in the agreement applied in the political and industrial relations sphere, but not the legal sphere, and that the parties had never intended to create legal rights.

${ }^{6}$ Part III of the Industrial Relations Act 1946 (as amended); this legislation has been the subject of a recent court challenge, discussed further below. Note that, despite its moniker, the Irish Labour Court is not part of the regular court system, but is a statutory industrial tribunal, comprised of representatives of unions and employers, and chaired by a government nominee. The Labour Court, depending on the nature of the dispute before it, may grant legally binding 'determinations' or 'recommendations', which are not legally binding.

${ }^{7}$ Part IV of the Industrial Relations Act 1946 (as amended); this legislation has also been the subject of a recent court challenge, discussed further below..
} 
Orders (EROs), which, when confirmed by the Labour Court, set legally binding minimum wages and conditions of employment for workers in the sectors covered. Prior to 2011, EROs provided: for minimum sectoral rates of pay in excess of the national minimum wage; for sectoral pay scales, based on length of service and skill level; for sectoral overtime payments and premium payments to those required to work on Sundays; and for benefits for employees in the relevant sectors that were not imparted by general labour legislation (most notably, a right to sick pay). Thus, both the REA and JLC systems represent a significant departure from the Irish (indeed, Anglo-American) norm, ${ }^{8}$ in that terms and conditions of employment are not settled through direct contractual negotiations between the employer and its workers. Instead, in Ewing's terms, these systems approximate a 'regulatory' model of collective bargaining that is premised on the idea that trade unions are involved in a process of rule-making that has an impact beyond their members (or members' immediate colleagues). Here, collective bargaining takes on an explicit public role, as employment standards are set, and applied, not only for employers that recognise trade unions and union members, but for enterprises which do not engage in collective bargaining. ${ }^{9}$

Voluntary bargaining at national level was a hugely important feature of labour relations in Ireland between 1987and 2010. During this period, a series of social pacts was concluded between the social partners; the State; the unions (represented by the only trade union confederation, the Irish Congress of Trade Unions- ICTU); and the employers (represented primarily by the main employers' association, the Irish Business and Employers Confederation- IBEC- but also by sector specific

\footnotetext{
${ }^{8}$ Bogg, A. The Democratic Aspects of Trade Union Recognition (Oxford, Hart, 2009).

${ }^{9}$ Ewing, K.D. 'The Function of Trade Unions' Industrial Law Journal (2005), 34(1), p. 1.
} 
groups, like the Construction Industry Federation). ${ }^{10}$ The social pacts each ran for three years, focusing on issues of pay (for the public, and unionised private, sector), tax reform and a range of other socio-economic issues. ${ }^{11}$ Thus, the Irish trade union movement (and the main employer's representative groups) had a strongly institutionalised, and State-sanctioned, role in national socio-economic governance. The bargaining and implementation processes under the 'social partnership' process were voluntary, with unilateral withdrawal by any party possible at any time; in particular, the government was free to treat the agreements as advisory documents choosing which issues to fully implement, subject, of course, to industrial relations and political considerations. However, a number of key labour law measures were agreed, which were then progressed through the normal legislative process; for example, legislation on a national minimum wage ${ }^{12}$ and throughout the period, agreements between public sector management and trade unions on public sector pay, reform and management measures were agreed and, almost without exception, implemented. The social partnership agreements also contained industrial peace clauses, and an elaborate institutional structure for the resolution of disputes relating to their interpretation or implementation. The Irish social partnership model attracted a wave of attention from academics and policy-makers all over the world, ${ }^{13}$ which focused on how Ireland, with its historically antagonistic, fragmented Anglo-Saxon industrial relations system, was capable of maintaining such a distinctive, corporatiststyle system of socio-economic governance. Furthermore, the social partnership era coincided with the 'Celtic Tiger' period of astonishing growth in wealth creation and

\footnotetext{
${ }^{10}$ All of the agreements can be accessed at http://www.taoiseach.gov.ie/eng/Publications/Publications Archive/ (accessed 20 November 2013). ${ }^{11}$ See Doherty, M. 'It Must Have Been Love...But It's Over Now: The Crisis and Collapse of Irish Social Partnership' Transfer: European Review of Labour and Research (2011), 17(3), p. 371.

${ }_{12}$ The National Minimum Wage Act 2000.

${ }^{13}$ See, for example, Baccaro, L. 'The Constitution of "Democratic" Corporatism in Italy' Politics and Society (2002), 30(2), p. 327.
} 
employment. ${ }^{14}$ It seemed that Ireland had struck labour relations gold; a model that allowed employers free reign (legally speaking) in their choice to deal, or not ,with trade unions, but which incorporated the trade union movement in processes of socio-economic governance. Not only that, but, in a country accustomed to high unemployment rates (approximately $20 \%$ in the late 1980s), high levels of emigration and decades of economic stagnation, here was a model that delivered unprecedented economic success, combined with historically low levels of industrial conflict.

\section{Ooops!...We Did it Again}

As is now well known, all that glittered in Ireland certainly was not gold, and a severe economic, financial and social crisis has engulfed the country (and, to varying degrees, most of the Western world) over the past five years. After recording real Gross Domestic Product (GDP) growth of more than 5\% in 2007, in 2009, real GDP in Ireland shrank by the same figure. The unemployment rate rocketed from under $5 \%$ in January 2007 to more than $15 \%$ by January 2012 and unemployment in the construction sector rose by $60 \%$ in just four years from 2008 to $2012 .{ }^{15}$ In broad terms, since 2008, Ireland has experienced a rapid deterioration in the public finances, a collapse in the housing market and construction sector, and a liquidity crisis for the banking system. ${ }^{16}$ While international economic events have impacted almost everywhere, worries had long been expressed about the light regulation of

\footnotetext{
${ }^{14}$ O'Connell, P.J. Astonishing Success-Economic Growth and the Labour Market in Ireland (Geneva, ILO, 2000).

${ }^{15}$ Figures from Eurostat (2013); http://epp.eurostat.ec.europa.eu/portal/page/portal/eurostat/home/ (accessed 20 November 2013).

${ }^{16}$ O' Kelly, K. 'The End of Social Partnership in Ireland?' Transfer: European Review of Labour and Research (2010), 16(3), p. 425.
} 
financial institutions (domestic and otherwise) and an over-heated property market in Ireland. ${ }^{17}$ The 'bursting' of national financial and housing bubbles, coupled, crucially, with the government's 2008 decision (endorsed by the EU) to State-guarantee all banking debt, has resulted in a particularly severe crisis in Ireland.

The initial response of the Irish government and employers was to seek a renegotiation of a wage agreement (providing for modest pay increases) struck in 2008. However, in March 2009, the government unilaterally introduced an emergency budget, imposing pay cuts for all public servants. ${ }^{18}$ Attempts to negotiate a new pact continued throughout 2009 and, in December, appeared to be on the verge of successful conclusion. However, a last minute revolt by government deputies over aspects of the deal relating to public sector reform led to the government withdrawing and the effective end of the Irish social partnership process. ${ }^{19}$ The December 2009 budget again cut public sector pay. In March 2010, with the partnership process moribund, the public sector unions and employers concluded a new four-year Public Service Agreement (the 'Croke Park Agreement'), ${ }^{20}$ under which it was agreed to protect public sector pay levels in exchange for a reduction in employee numbers and a substantial commitment to 'reform', including the redesign of work processes. Despite considerable opposition to the deal amongst, and within, many unions, the Public Services Committee of the ICTU accepted the deal in June. In November 2010, the Irish government accepted the terms of an International Monetary Fund-EU rescue package, totalling approximately $€ 85$ billion, outlined a four-year austerity plan, and, in the December

\footnotetext{
${ }^{17}$ See, for example, the account of Ireland as a 'financial Wild West' in the New York Times, 1 April 2005.

${ }^{18}$ See the Financial Emergency in the Public Interest Act 2009 (known as the 'FEMPI' legislation; further FEMPI Acts were introduced in 2010 and 2013).

19 O' Kelly, cit., (n 166).

${ }^{20}$ Available at http://per.gov.ie/croke-park-agreement/ (XXXXXXXXXXX?
} 
budget, introduced $€ 6$ billion of tax increases, new charges and levies and severe welfare and public spending cuts (including a cut in the minimum wage). A general election in early-2011 brought a new coalition government to power, which has committed to carrying out the terms of the bail-out package. The budgets of 2011, 2012 and 2013 have introduced a range of further austerity measures (including further levies and charges and swingeing cuts to public spending). In 2013, the government also announced it wanted to renegotiate the terms of the Croke Park Agreement. A deal emerged (commonly referred to as 'Croke Park Two'), which was rejected in a ballot by a majority of public service workers. ${ }^{21}$ Further negotiations produced a modified deal, the 'Haddington Road Agreement', which, nonetheless, provided for another round of pay cuts, increment freezes and substantial changes to working conditions for public servants. At the time of writing, all but one public sector trade union (representing secondary school teachers) has accepted the terms of this agreement. In the next sections, the changes occasioned by the crisis, and those wrought by the terms of the IMF-EU deal, will be examined.

\section{Standard-setting, the Troika and the Courts}

A crucial point to make at this juncture is that relative to the demands made of, and changes made to, labour law in the other countries featured in this volume, those examined in this article almost pale into insignificance. However, this leads to some important questions about the approach of the supra-national institutions in question, and most notably, of course, about the role of the European Commission and the European Central Bank, to which we will return below.

${ }^{21}$ http://www.rte.ie/news/2013/0416/381586-croke-park-agreement/ (accessed 20 November 2013). 
Nonetheless, the dramatic changes wrought in Spain and Greece do not quite have parallels in the Irish case; generally speaking the employment legislative framework has remained largely, though not exclusively, intact. The Irish Memorandum of Understanding (MoU) agreed with the Troika and dated December $12010,^{22}$ unsurprisingly focuses primarily on measures relating to fiscal consolidation and financial sector reforms. However, the MoU does address 'structural reforms' relating to the labour market. ${ }^{23}$ The most significant pledge for the purposes of this article was to commission an independent review of the REA and JLC arrangements, with terms of reference and follow-up actions to be agreed with the Commission. This review was to be carried out in order to ensure there were no 'distortions' of wage conditions across sectors associated with the presence of sectoral minimum wages in addition to the national minimum wage. The review of the ERO and REA systems was published in May 2011 and recommended reform, rather than abolition. ${ }^{24}$ Before the government took any action, events were somewhat overtaken when the Irish High Court declared that the legislation allowing the imposition of terms and conditions of employment by means of an ERO was unconstitutional. ${ }^{25}$ The Minister for Jobs, Enterprise and Innovation moved swiftly to enact new legislation to re-establish, with significant reforms, the ERO/REA systems; the Industrial Relations (Amendment) Act 2012. In terms of bolstering, or at least

\footnotetext{
${ }^{22}$ The $2010 \mathrm{MoU}$ and all subsequent documents relating to Ireland's bail-out are available at http://www.finance.gov.ie/viewdoc. asp?DoclD=6856 (accessed 20 November 2013).

${ }^{23}$ As noted above, the 2010 agreement pledged a reduction in the national minimum wage of approximately $11.5 \%$, which was implemented by the government in that year's budget. This was reversed by the new government, following negotiations with the Troika in May 2011 (MoU May 2011).

${ }^{24}$ Duffy, K and Walsh, F., Report of Independent Review of Employment Regulation Orders and Registered Employment Agreement Wage Setting Mechanisms (available at http://www.djei.ie/publications/employment/2011/Report ERO REA.pdf; accessed 20 November 2013).

${ }_{25}$ John Grace Fried Chicken Ltd \& Ors v Catering Joint Labour Committee \& Ors [2011] IEHC 277. For full discussion of this case see Doherty,M. 'Battered and Fried? Regulation of Working Conditions and Wage-Setting after the "John Grace" Decision' Dublin University Law Journal (2012), 35, p 97.
} 
maintaining, legally binding collective bargaining structures (in the case of the REAs) and social partner involvement in legally binding wage-setting mechanisms (in the case of the JLCs), the decision of the Irish government, with the consent of the Troika, to re-establish the ERO/REA systems, rather than simply abolish them, was noteworthy. However the provisions of the 2012 Act did come in for some criticism, first, for de-prioritising the role of the social partners in negotiating and policing the regulation of terms and conditions of employment (the Act vests significant veto powers in the Minister of the day), and, secondly, by emphasising the establishment of statutory minimum standards in terms of employment rights rather than bargained terms and conditions of employment, which seek to improve upon the statutory 'floor'. ${ }^{26}$ It is worth commenting, too, that the enacted legislation ignored the recommendation of the ERO/REA review group, set up in accordance with the MoU, to establish a well-designed framework where collective bargaining (within the meaning of Article 28 of the Charter of Fundamental Rights of the European Union and relevant International Labour Organisation - ILO - Conventions) ${ }^{27}$ could take place. The 2012 Act certainly seemed to satisfy the Troika; references to it in the MoUs subsequent to its enactment simply required the Irish government to report 'on the impact on the labour market of reforms to sectoral wage-setting mechanisms undertaken under the programme'.28

However, another key decision of the Irish Superior Courts was delivered shortly after the enactment of the legislation. In McGowan \& Ors $v$ The Labour Court

\footnotetext{
${ }^{26}$ Doherty, cit., (n 25).

27 See C98, The Right to Organise and Collective Bargaining Rights Convention 1949; C154, The Collective Bargaining Convention 1981; and also the Collective Bargaining Recommendation of 1951 (No 91).

${ }^{28}$ MoU dated November 2012; see n 22, above.
} 
\& Ors ${ }^{29}$ the Supreme Court declared Part III of the Industrial Relations Act 1946, which established the REA system, and which the 2012 Act purports to amend, to be unconstitutional. The tone of the judgment and the language used by the Supreme Court are noteworthy. ${ }^{30}$ The Court notes (at paragraph 8) that the provisions of Part III appear 'somewhat anomalous' today and give rise to the 'prospect of burdensome restraints on competition for prospective employers and intrusive paternalism for prospective employees'. The fact that the erga omnes extension of collective agreements to cover all employers and workers in a sector is a well-established feature of employment law systems in a raft of other EU States did not seem apparent to the Court. It seems many workers in sectors formerly covered by JLCs and REAs (retail, construction, etc.), unless contractually protected, are now covered solely by the provisions of minimum wage legislation and other statutory minima where these exist. This is certainly the view of the Troika. In its summer 2013 review of Ireland, the Commission noted that the 2012 Act now seems inadequate and requires 'fast action' on a new framework to reinstate:

'a proper industrial relations management mechanism. Many aspects of the 2012 reform ought to be preserved, including the increased flexibility and consideration given to international competitiveness and relative wage levels in the EU, while the scope of REAs ought to be reduced'. ${ }^{31}$

\footnotetext{
29 [2013] IESC 21.

30 See Doherty, M. 'When You Ain't Got Nothin', You Got Nothin' to Lose... Union Recognition Laws, Voluntarism and the Anglo-model' Industrial Law Journal (forthcoming).

31 Economic Adjustment Programme for Ireland-Summer 2013 Review, p. 31 (http://ec.europa.eu/economy finance/publications/occasional paper/2013/op162 en.htm; accessed 20 November 2013)
} 
The Commission also notes approvingly that the Irish authorities aim to avail of the new reforms to reduce the number of sectors subject to EROs. Thus, with a little help from the Irish judiciary, all is on track. In the private sector, fewer workers are to be covered by sectoral terms and conditions of employment that exceed statutory minima and trade union involvement in setting legally binding terms and conditions of employment is to be reduced.

\section{Public Sector Reform (or 'make them an offer they can't}

\section{refuse...')}

'Ireland has been able to deliver public services with a public sector that is relatively small given the size of its economy and labour force.

(Social partnership) has been used as a potent instrument across all sectors to ensure the co-operation of Public Service unions with change and modernisation objectives, and to sort out industrial disputes... Nationally, Social Partnership has also led to a culture whereby consultations on significant legislative or policy changes will, as a matter of course, include consultation with the Social Partners. At a lower level there is also a growing awareness of the need to ensure that the views of business, employees/trade unions/citizens, and vulnerable groups, are taken into account when examining the implications of proposed policy changes. 
Ireland may want to move towards more delegated pay bargaining. ${ }^{, 32}$

The quotes above from the report into the Irish public service dates from 2008, but, according to its authors at the OECD, its main findings remain relevant, even though it was undertaken before the economic crisis. ${ }^{33}$ It is interesting, therefore, to reflect on the key approaches to addressing the crisis in Ireland, prescribed by the Troika and implemented by two successive Irish governments. Many of the broad parameters of the response are set out in the National Recovery Plan 2011-2014:34 these are subsequently repeated, modified and monitored in the successive MoUs with the Troika. The aim is a 9\% of GDP budgetary correction over the period. The plan provides for fiscal consolidation measures over its lifetime amounting to $€ 15$ billion; $€ 5$ billion to come via tax increases and $€ 10$ billion to come via reductions in public expenditure. The latter are to be achieved, in part by the reduction in numbers of public servants in the order of approximately 25,000 and by the generation of significant savings through the reform of work practices in the public sector. As of yet, compulsory redundancies have been avoided. This is, arguably, the main trade union success in the negotiations of the two public service agreements since 2010, the Croke Park and Haddington Road agreements. Numbers have been shed through early retirements, the non-replacement of departing staff, and a tight Employment Control Framework, which sets strict limits on any public sector recruitment. Nevertheless, Ireland's 'relatively small public sector' is now smaller (and being further reduced) at a time when demands on core public services (in

\footnotetext{
32 OECD, OECD Public Management Reviews: Ireland 2008: Towards an Integrated Public Service, (Paris, OECD Publishing, 2008) at, respectively, pps. 22, 74-5, 111.

${ }^{33} \mathrm{http}: / /$ www. oecd.org/gov/oecdpublicmanagementreviewsirelandtowardsanintegratedpublicservice.htm (accessed 20 November 2013). ${ }^{34}$ http://www.budget.gov.ie/The\%20National\%20Recovery\%20Plan\%202011-2014.pdf (accessed 20 November 2013).
} 
health, education and, particularly in the context of high unemployment, social security and welfare) are increasing.

In the area of work practice reform, the parameters are set out in the Haddington Road Agreement. ${ }^{35}$ Unlike the reforms in Greece and Spain, these were, at least, negotiated with the public service trade unions (although the 'negotiation' process will be discussed further below). Nonetheless, some of the concerns expressed by the other contributors in this volume in relation to the impact of the reforms on certain groups, particularly women and those with family responsibilities, are echoed here. The Agreement outlines a number of general reform principles and goes on to provide further detail on these at a sectoral level. Of particular interest to this article are the provisions for:

- Additional working hours for public servants;

- greater use of redeployment of public servants (up to $45 \mathrm{~km}$ from the current work location or of the home address);

- review and reform of work-sharing arrangements, to make operation of the system less of a 'management challenge';

- review and reform of flexible work arrangements (flexi-time) to better reflect the 'current needs of public service organisations'.

On publication of the Agreement, it was quickly pointed out by that the proposals could have the potential for a 'disproportionate and negative impact on women employed in the public service' and could 'disproportionately disadvantage men and

${ }^{35}$ http://per.gov.ie/haddington-road-agreement/ (accessed 20 November 2013). 
women with caring responsibilities in the public sector ${ }^{36}$ It remains to be seen, in the implementation of the Agreement, whether this turns out to be the case, but, clearly, the direction of the reform proposals cannot be said to be going in a family-friendly direction. It should also be noted here that a series of reforms since 2010 have disproportionately impacted on new entrants to the public service (predominantly younger workers), who have entered the service on considerably lower salary scales, and with inferior pension entitlements, than those previously applicable.

The reform measures implemented have, of course, important consequences for the national finances, public servants and those dependent on public services. However, the manner in which the reforms have been implemented may have even more lasting effects. It was noted in section 3, notwithstanding the praise heaped upon the social partnership model during Ireland's 'boom' years, that the government and employers quickly abandoned the model in 2010. In 2013, the government similarly announced it wished to re-negotiate the terms of the 2010 Public Service Agreement (Croke Park), which still had at least a year to run. The manner of the 'negotiation' is noteworthy. As noted above the original re-negotiated deal ('Croke Park Two') was rejected by public sector union members following a ballot. Following another round of negotiations, modified proposals were presented to union members in the Haddington Road Agreement. This time, the government was less inclined to leave matters to the vagaries of trade union democracy. In a remarkable intervention, the government published, at the same time as the Agreement emerged, what was subsequently enacted as the Financial Emergency Measures in the Public Interest Act (FEMPI) 2013. This legislation provides that members of unions that refuse to sign up to the Haddington Road Agreement will simply have

\footnotetext{
${ }^{36} \mathrm{http}: / / \mathrm{www}$.imo.ie/news-media/press-releases/2013/alliance-of-unions-for-a-l (accessed 20 November 2013).
} 
their pay cut, and terms and conditions of employment altered, by legislation. The protections of the Agreement (in relation to no compulsory redundancies, for example) will not apply to the members of such unions. ${ }^{37}$ The 'culture of partnership' noted approvingly by the OECD, it seems, has somewhat soured.

Nor has the OECD's suggestion of a move to more delegated pay bargaining in the public service been accepted. Rather, pay across the public service is increasingly being determined by central government and, in particular, by the Department of Public Expenditure and Reform (DPER). Indeed, recent research reports that this Department has effectively become that which determines pay and general employment terms and conditions for all areas of the public service. ${ }^{38}$ It seems the 'line' departments and public sector management in sectors such as Health and Education are reduced to merely complying with the demands of DPER. Following the banking collapse, in a situation where the majority of the domestic banking sector is now State-owned, this applies also to the terms and conditions of employees in this sector. ${ }^{39}$

Therefore, what can be seen in the conduct of public sector industrial relations in Ireland is a move towards centralised, command-and-control governance. The Haddington Road Agreement, with its strongly sectoral focus, has weakened the trade union centre, particularly the ICTU, and caused tensions between trade unions. The government's unilateral withdrawal from social partnership, unilateral insistence

\footnotetext{
${ }^{37}$ At the time of writing (September 2013) all but one of the public service trade unions that balloted members on the Agreement have accepted its terms (many of these unions had rejected 'Croke Park Two'). The only union to date that has refused to accept the deal is the Association of Secondary School Teachers in Ireland (ASTI); http://www.irishtimes.com/news/ireland/irish-news/governmentstands-firm-after-asti-rejects-pay-deal-1.1535236 (accessed 20 November 2013).

${ }^{38}$ Trif, A. and Doherty, M. 'The Impact of the Crisis on Collective Bargaining in Romania and Ireland' (paper presented at the Industrial Relations in Europe (IREC) Annual Conference, Bucharest, Romania, September 2013) 39 Ibid.
} 
of the re-negotiation of the original Croke Park agreement, and threats of unilateral alteration to public service terms and conditions of employment has greatly damaged relations of trust with the unions and with public servants. The implications of this if and when Ireland returns to some sort of economic stability remain to be seen; clearly, though, the relative industrial peace delivered over the previous quarter of a century will be much harder to negotiate in the event of an economic upturn.

\section{Conclusions}

'In short, today is a good day for Ireland and the Irish people. It provides clear evidence that determined implementation of a comprehensive reform agenda can decisively turn around a country's economic fortunes and put it back on a path of sustainable growth and rising employment' ${ }^{40}$

We live in extraordinary times. As such, it is no surprise that labour law, like all areas of contemporary socio-economic regulation, is undergoing rapid and, potentially, transformative change, especially in countries where the crisis has been most deeply felt. This article has examined key changes in two areas; sectoral wage-setting in the private sector and employment terms and conditions in the public sector. In the former, the emphasis of the Troika demands, and the focus of the Irish judiciary, has been on moving away from prioritising the role of the social partners in negotiating and 'policing' regulation of terms and conditions of employment, and moving towards

\footnotetext{
${ }^{40}$ Olli Rehn, European Commissioner for Economic and Monetary Affairs and the Euro and vice president of the European Commission, November 14, 2013 (http://europa.eu/rapid/pressrelease MEMO-13-997 en.htm; accessed 20 November 2013).
} 
the establishment of statutory minimum standards and away from bargained terms and conditions of employment. In the heavily unionised public sector, the move has been to downgrade terms and conditions of employment, particularly for new entrants, and to move away from a consensual, partnership approach to collective bargaining. The Irish government has resisted calls to abolish the sectoral wagesetting mechanisms in their entirety and has at least, in contrast to the governments in Greece and Spain, negotiated a settlement with public sector trade unions.

Nonetheless, a clear overall pattern can be ascertained.

In both areas, the model of the State supporting autonomous social partner involvement in setting terms and conditions of employment has been, perhaps fatally, undermined. The move is clearly towards setting legislative standards, which seem to operate as a 'ceiling' rather than a 'floor'; in the public sector, members of trade unions that do not accept the government's 'negotiation' position will simply have terms and conditions set by law. Achtsioglou and Doherty have argued that this seems to run counter to various guarantees of social partner autonomy under European law. ${ }^{41}$ Article 11 of the European Convention on Human Rights (ECHR), for example, guarantees the right to form and join trade unions. According to the European Court of Human Rights, this encompasses a right not to have prohibitions imposed on the freedom of trade unions to engage in collective bargaining. ${ }^{42}$ Article 6(3) of the new Treaty on European Union (TEU) states that 'fundamental rights, as guaranteed by the (ECHR) and as they result from the constitutional traditions common to the Member States, shall constitute general principles of the Union's law'. Moreover, Article 28 of the Charter of Fundamental Rights provides for the right of

\footnotetext{
${ }^{41}$ Achtsioglou, E. and Doherty, M.,'There Must Be Some Way Out of Here...The Crisis, Labour Rights and Member States in the Eye of the Storm' European Law Journal (2013), 19, (online).

${ }^{42}$ Demir and Baykara v Turkey (Application No 34503/97, 12 November 2008).
} 
trade unions to negotiate and conclude collective agreements and, in cases of conflicts of interest, to take collective action to defend their interests, including strike action. Lastly, Article 152 of the Treaty on the Functioning of the EU (TFEU) states that the Union 'recognises and promotes the role of the social partners' at Union level, whilst the Treaty (Articles 153-155) grants the social partners at both Union and Member State level unique and privileged roles in the legislative process, underlining the importance that the Union gives to collective autonomy as a core self-regulating mechanism of industrial relations. However, it has also been argued that developments in Ireland are perfectly consistent with recent jurisprudence of the Court of Justice, which also militates against collective approaches to labour market regulation. In a line of judgments, (commonly referred to as the 'Laval Quartet') Laval, Viking, Rüffert and Luxembourg, ${ }^{43}$ the Court has severely restricted the rights of trade unions (and Member States) to act in order to protect collective agreements in cases where the rights of free movement of services or establishment are involved. As Achtsioglou and Doherty note:

'Judicial interventions by the European Court in policy areas that have a direct and immediately tangible impact on the lives of citizens, and where national arrangements are the product of long-standing social settlements, such as industrial relations, will, of course, be controversial and more likely to be the subject of popular and/or political resistance. Additionally, however, in Greece and Ireland the role played by other EU institutions (especially the Commission) in the context of the economic crisis and, in particular, the terms

\footnotetext{
${ }^{43}$ Case C-341/05 Laval v Svenska Byggnadsarbetareförbundet [2007] ECR I-11767; Case C438/05 International Transport Workers' Federation and Finnish Seamen's Union v Viking Line ABP [2007] ECR I-10779; Case C-346/06 Rüffert v Land Niedersachsen [2008] ECR I-1989; and Case C319/06 Commission v Luxembourg [2006] ECR 1-8673.
} 
of the economic support packages have clearly damaged public support for the EU project'. ${ }^{44}$

In Greece, Ireland and Spain the various labour law measures undertaken during the crisis are likely to have serious, negative, and lasting, implications for popular conceptions of democratic legitimacy, and for the process of further EU integration.

As the contributions to this volume have shown, in each country, the underlying causes of the crises, and their impacts, are varied. Furthermore, the labour law, labour relations and social policy institutional frameworks differ significantly. However, in all cases the 'medicine' to be taken has been the same; 'structural reforms' of the labour market, which downgrade collective bargaining rights and procedures, and a contraction of the public sector and downgrading of the terms and conditions of employment therein. In all three countries, it is arguable, certain categories of workers (notably younger workers and females) have been disproportionately affected by the reforms. It has already been noted, by contrast with the Greek and Spanish cases, that little in terms of legislative reform in Ireland was demanded by the Troika, particularly in relation to the general labour law framework. The explanation for this, undoubtedly, reflects the comparatively light nature of Irish labour law regulation. As noted, where legislation exists, it focuses almost exclusively on providing a floor of minimum rights for individual workers. Statutory provisions supporting collective bargaining are almost non-existent. ${ }^{45}$ Thus, bargained standards that exceed statutory minima (in terms of pay, working time, etc.) have been traditionally achieved by trade unions through the deployment (or threat) of industrial action, in the public sector by virtue of the (legally non-binding)

\footnotetext{
${ }_{45}^{44}$ Achtsioglou and Doherty, cit., (n 41).

${ }^{45}$ Doherty, cit., (n 35).
} 
public service agreements, or in sectors, like retail and hotels covered by EROs or REAs. The last two mentioned, in particular, have been the areas where the Troika did demand government action. ${ }^{46}$ Thus, although Ireland already has a lightly regulated labour market, ${ }^{47}$ it was required to review and reform the few areas of regulation that provide for collectively bargained standards and that allow workers to benefit from collective representation without having to first 'trigger' their rights. Achtsioglou and Doherty point out that what is significant 'is the extent to which labour market regulation is to be 'micro-managed' by the EU institutions; even in relatively "neo-liberal" Ireland' ${ }^{48}$

The words of Commissioner Rehn quoted above, clearly point to Ireland as the 'star pupil' in this particular class. However, if Ireland is the success story, taken together, the contributions in this volume clearly beg the question: after the crisis, where next for (what remains of) 'social Europe'?

\footnotetext{
${ }^{46}$ Doherty, M., 'Emergency Exit? Collective Bargaining, the ILO and Irish Law', ELLJ (forthcoming).

47 In the World Bank's Doing Business Report 2012, Ireland is number 10 in the 'rankings on the ease of doing business' list; Greece is number 100 and Spain number 44 (available at http://www.doingbusiness.org/reports/global-reports/doing-business-2012; accessed November 20 2013).

${ }^{48}$ Achtsioglou and Doherty, cit., (n 41).
} 